\title{
Assessment and Modeling of Household-Scale Solar Water Heater Application in Zambia: Technical, Environmental, and Energy Analysis
}

\author{
Mehdi Jahangiri $\mathbb{D}^{1},{ }^{1}$ Esther T. Akinlabi $\mathbb{D}^{2,3}$ and Sam M. Sichilalu $\mathbb{( D}^{2,4}$ \\ ${ }^{1}$ Department of Mechanical Engineering, Shahrekord Branch, Islamic Azad University, Shahrekord, Iran \\ ${ }^{2}$ Department of Mechanical Engineering Science, Faculty of Engineering and the Built Environment, University of Johannesburg, \\ Johannesburg, South Africa \\ ${ }^{3}$ Directorate, Pan African University for Life and Earth Sciences Institute, Ibadan, Nigeria \\ ${ }^{4}$ Department of Electrical and Electronic Engineering, School of Engineering University of Zambia, Lusaka, Zambia
}

Correspondence should be addressed to Mehdi Jahangiri; jahangiri.m@iaushk.ac.ir

Received 18 December 2020; Revised 22 May 2021; Accepted 20 June 2021; Published 7 July 2021

Academic Editor: Francesco Riganti-Fulginei

Copyright (C) 2021 Mehdi Jahangiri et al. This is an open access article distributed under the Creative Commons Attribution License, which permits unrestricted use, distribution, and reproduction in any medium, provided the original work is properly cited.

Solar water heaters (SWHs) are one of the most effective plans for general and easy use of solar energy to supply hot water in domestic and industrial sectors. This paper gives the first-ever attempts to assess the optimal localization of SWHs across 22 major cities in Zambia, as well as determine the possibility of hot water generation and model the greenhouse gas (GHG) emission saving. The climate data used is extracted by using the MeteoSyn software which is modeled in $\mathrm{TSOL}^{\mathrm{TM}}$. Results show the high potential of GHG emission reduction due to nonconsumption of fossil fuels owing to the deployment of SWHs, and three cities Kabwe, Chipata, and Mbala had the highest GHG mitigation by $1552.97 \mathrm{~kg} / \mathrm{y}, 1394.8 \mathrm{~kg} / \mathrm{y}$, and $1321.39 \mathrm{~kg} / \mathrm{y}$, respectively. On average, SWHs provide $62.47 \%$ of space heating and $96.05 \%$ of the sanitary hot water requirement of consumers. The findings have shown the potential for the deployment of SWHs in Zambia. The techno-enviro study in this paper can be used by the policymakers of Zambia and countries with similar climates.

\section{Introduction}

Residential and commercial buildings account for $54.7 \%$ and $45.3 \%$ of total energy consumption in the building sector, respectively. Only $9 \%$ of energy use in the building sector is provided by renewable energy and the rest by fossil fuels [1]. As it is shown in Figure 1 [2,3], the highest energy consumption in the building sector is related to space and water heating by $37 \%$ and $12 \%$, respectively. This also highlights the reduction in $\mathrm{CO}_{2}$ by using solar water heater $(\mathrm{SWH})$ systems $[4,5]$, more suitability of SWH compared with electric water heaters (EWHs) [6,7], and the necessity of higher application of SWH [8]. SWH systems are one of the most common applications of solar systems [9].

Among various renewable energies, solar energy plays an important role [10-12]. Although many advances have taken place in this area, the extensive implementation of SWH sys- tems has been hindered by factors such as associated high costs [13]. Due to their simple operation and minimum maintenance requirements, SWHs are the best option for the domestic sector [13]. These factors as well as the fact that they are environmentally friendly have attracted attention to SWHs at both domestic and industrial scales [9]. The costeffectiveness of SWH systems is dependent on government subsidies and the price of fossil fuels used for water heating $[14,15]$. All over Europe, except for Denmark, Greece, and Finland, financial incentives are offered to encourage SWH installation [16] and most of the European countries have removed the value-added tax on solar equipment [17]. It is estimated that replacing EWH with SWH would save $940000 \mathrm{kWh}$ of energy annually [10]. It should be mentioned that due to factors such as the price of fossil fuels, subsidy rate, and radiation rate, the capital recovery period differs from one place to another [9]. The leading countries in terms 


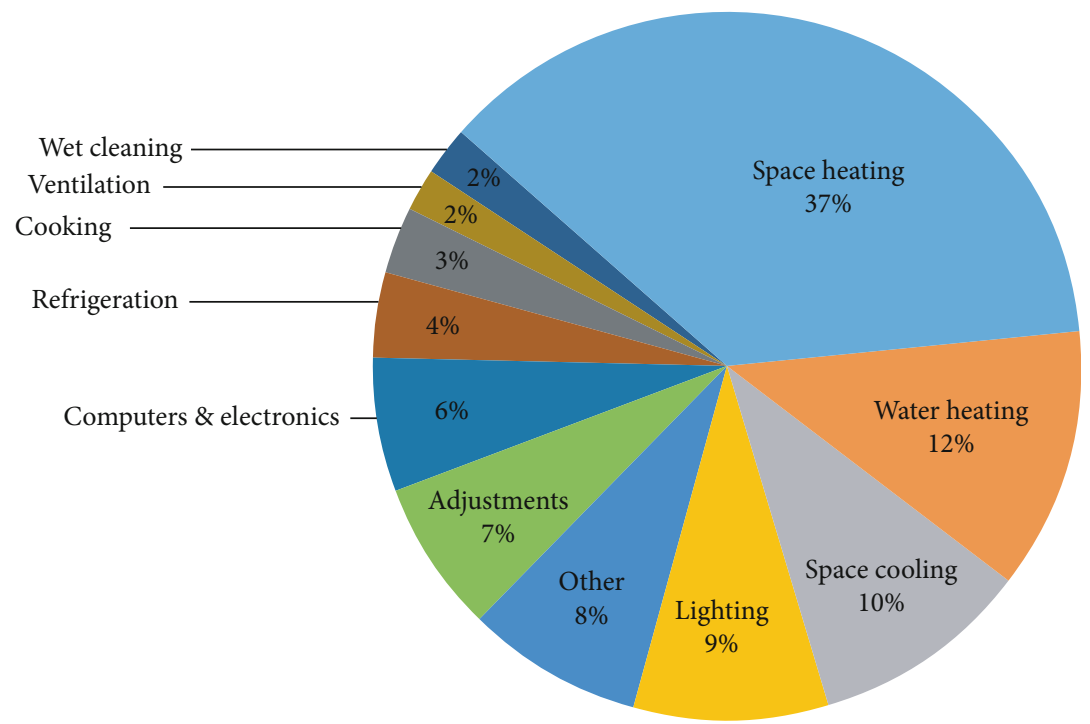

FIgURE 1: Building sector energy consumption in 2010 by demand [2].

of SWHs are China, Turkey, India, Brazil, and Germany [9], although regarding $\mathrm{kWh}$ of thermal energy produced per 1000 people, Austria (419), Cyprus (412), and Israel (400) occupy the first to third rankings [18].

In $2014,91 \%$ of the heat produced by SWHs has been used for hot water consumption, $63 \%$ in small residential buildings and $28 \%$ in complex buildings, hotels, schools, etc., $6 \%$ for swimming pools, $2 \%$ for simultaneous supply of sanitary hot water and space heating, and $1 \%$ in combined solar systems like industrial processes [18]. As it is shown in Figure 2, solar heating capacity of SWHs in 2015 was $435 \mathrm{GW}$ that was obtained from solar collectors covering an area of 622 million $\mathrm{m}^{2}$ [19]. Figure 3 illustrates the percentage of SWH use in various continents [9]. From this figure, it is clear that only $0.3 \%$ of SWH usage occurs in Africa which is mostly concentrated in Morocco and Tunisia [20, 21].

A number of studies on SWH use around the world are reviewed in the following [5].

Benli [22] performed a potentiometric study on SWH for providing the required hot water in Turkey. The study showed an improvement in energy security and reduced the dependence on the gas imported from Russia and Iran. The study locations were six different cities in Turkey. Two types of collectors with different absorber materials (vacuum tube, galvanized sheet) were used. Results suggested that the galvanized sheet absorber was superior for the provision of hot water in Turkey. Furthermore, they observed that due to inadequate climate conditions and purchasing power loss, SWH was less used in the northern and eastern parts of Turkey.

Mamouri and Bénard [1] evaluated the SWH potential for Michigan State, US. They used the SAM software for analyzing data from 26 distributed points in the state and validated the software results by experimental data of a collector in Michigan State University. Results indicated that evacuated tube SWHs were suitable for domestic water consumption (producing 63.8\% of required hot water and an annual reduction of $1664 \mathrm{~kg}$ in $\mathrm{CO}_{2}$ ) with a capital recovery period of 8 years. They also presented some experimental equations for finding the optimal collector area given the required hot water and location under study. The effect of parameters such as heat loss coefficient on the thermal performance of the system was also evaluated [23, 24].

Chang et al. [7] studied the performance of SWH for water preheating in industrial processes in Taiwan. The studied sample was a chicken slaughterhouse, and the results were compared with a student's dormitory with similar hot water consumption patterns. Results suggested that the temperature of incoming water, the rate of solar radiation, and the load pattern were effective factors on SWH efficiency. Evaluating the capital recovery period showed the costeffectiveness of SWHs for industrial heating processes [25, 26].

Bowa et al. [27] reviewed the current status of solar sources, obstacles, challenges, and future governmental plans for enhancing solar technology in Zambia. They took advantage of others' experiences and called for further research in this area. They suggested that Zambia had high solar potential, and given the current growth in energy demand, solar technology was the best option to be combined with other existing sources for providing sustainable energy.

Pahlavan et al. [28] evaluated the use of flat-panel SWHs at 37 stations in Algeria. They used the TSOL software to analyze the results, and their scale was residential. The most important parameter studied was the solar fraction, based on which the top 3 stations were selected. Also, the total amount of heat generated for space heating and sanitary water heating was calculated to be about $15 \mathrm{MWh}$ and 10 MWh, respectively. The rate of nonemission of pollutants was estimated at 57 tons per year.

Jahangiri et al. [29] evaluated the use of flat-panel SWHs in Canada using the TSOL software. The simulations were performed to provide the heating needed by a family of four in 10 different Canadian provinces. The highest percentage of total heat supply with $35 \%$ was related to the Regina station. At the Regina station, about $94 \%$ of the heat required for 


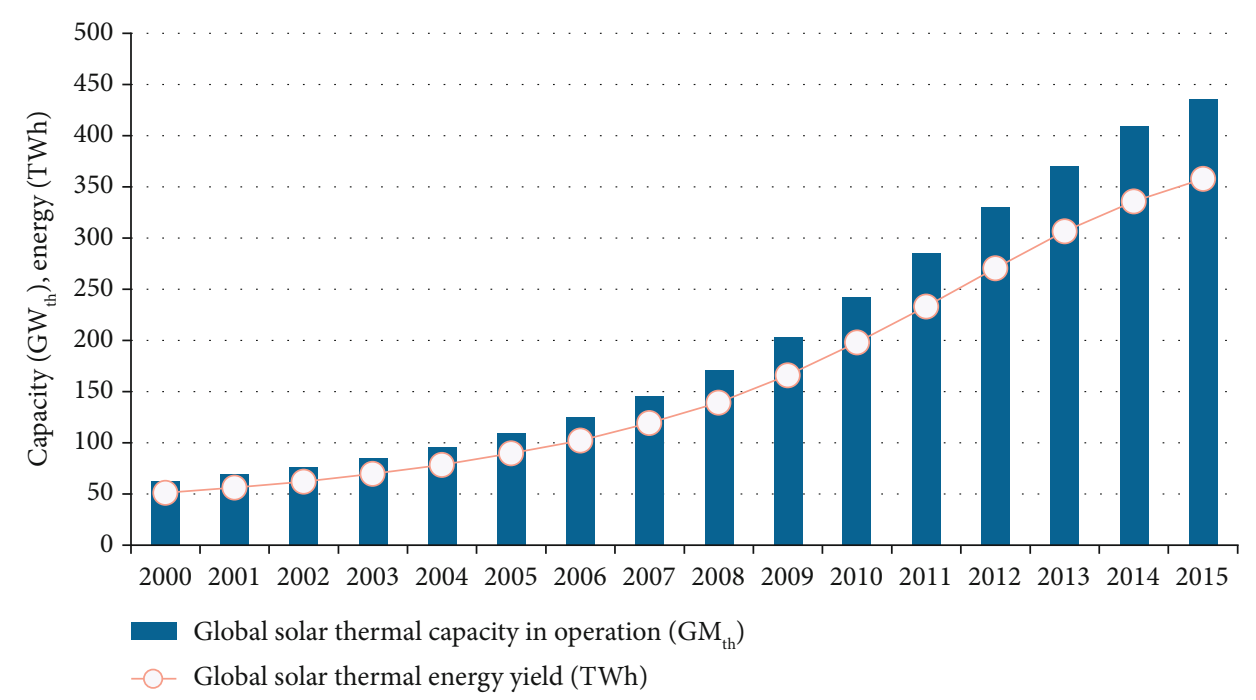

FIGURE 2: Global solar thermal capacity in operation and annual energy yields 2000-2015 [9].

sanitary water consumption and $25 \%$ of the heat required for space heating are provided by SWHs. It was also stated as a general result that the potential of using SWHs to provide sanitary hot water is very high.

Siampour et al. [30] conducted a technical-environmental assessment and ranking analysis for the use of a flat plate and evacuated tube SWHs at 45 stations in Turkey. Simulations and rankings were performed by TSOL and GAMS software, respectively. The results showed the superiority of evacuated tube SWHs on the flat-plate SWHs in all stations. The annual total heat production for the studied stations and the amount of preventing the emission of pollutants for flat-plate SWHs and vacuum tube SWHs were about 133 MW and 68.4 tons and about 229 MW and 93.4 tons, respectively. The top stations were also Akhisar, Bodrum, Finike, Hakkari, and Iskenderun.

Nowadays, very few countries can produce their own energy independently [31]. This fact compels other countries such as Zambia to present applicable strategies on renewable energies, given the constraints of fossil fuels and their adverse environmental effects, and formulate plans for their sustainable development and economic growth. Zambia has the potential to harness solar energy using SWHs; however, the lack of consolidated data on all parameters is a key challenge. Despite the fact that SWHs are reliable and cost-effective in producing the required hot water $[32,33]$, for any investor and government to make a decision on exploitation, there is an urgent need to conduct research on key parameters for the deployment of SWHs in Zambia.

Therefore, this paper is the first ever to determine the possibility of hot water generation using SWHs with a case study down across the country in 22 different cities. Also, according to previous studies, it is observed that the number of similar works was very low, which were not in the same climate of Zambia. In the rest of the studies so far, the analysis has not been performed over a period of one year or all possible losses have not been considered; in other words, the complete energy analysis of the solar heating cycle has not been performed. The studied parameters are solar fraction at each station, the share of heat produced for sanitary hot water at each station, the share of heat for space heating at each station, the share of heat produced by auxiliary woodfired boiler at each station, and savings in $\mathrm{CO}_{2}$ emissions. Finally, in addition to determining the potential of each station, the best station for investing in SWH systems is analyzed. In addition, this paper's techno-enviro study carried out can be used for countries with similar climates. Also, the model selected for the study and the way of analysis can be used for other regions of the world with different climatic conditions. In addition, the results of the present work can help welfare, social, and cultural development in Zambia by helping decision-makers in the field of solar heating in Zambia, as well as domestic and foreign investors.

This paper is organized as follows: Section 2 of this paper presents the case study and overall country solar energy resource atlas. Section 3 presents the mathematical models and modeling methodology, while Section 5 is the result discussions. Section 7 presents the conclusion of the paper.

\section{The Case Study}

Zambia is a member of the Southern African Development Community together with the neighboring 7 countries: Angola, Congo, Malawi, Mozambique, Zimbabwe, Botswana, and Namibia [34-36], with a population of 14 million people and an area of $752681 \mathrm{~km}^{2}$. The current electrification rate in Zambia is $45 \%$ in cities and $3 \%$ in villages which are planned to increase, respectively, to $90 \%$ and $51 \%$ by 2030 [37].

The consequences of an annual 5\% growth in Zambia's economy during the last 10 years have led to an escalation of energy demand leading to a significant increase in renewable energy demands. In 2015, private sector participation in the renewable energy sector became effective [38]. Zambia has faced many challenges on energy deficit and has failed to meet the demand in both rural and urban regions since the start of drought in 2016 [27]. To mitigate the energy deficit and to achieve sustainable development, Zambia has put solar energy as the first priority [27]. Despite the fact that 


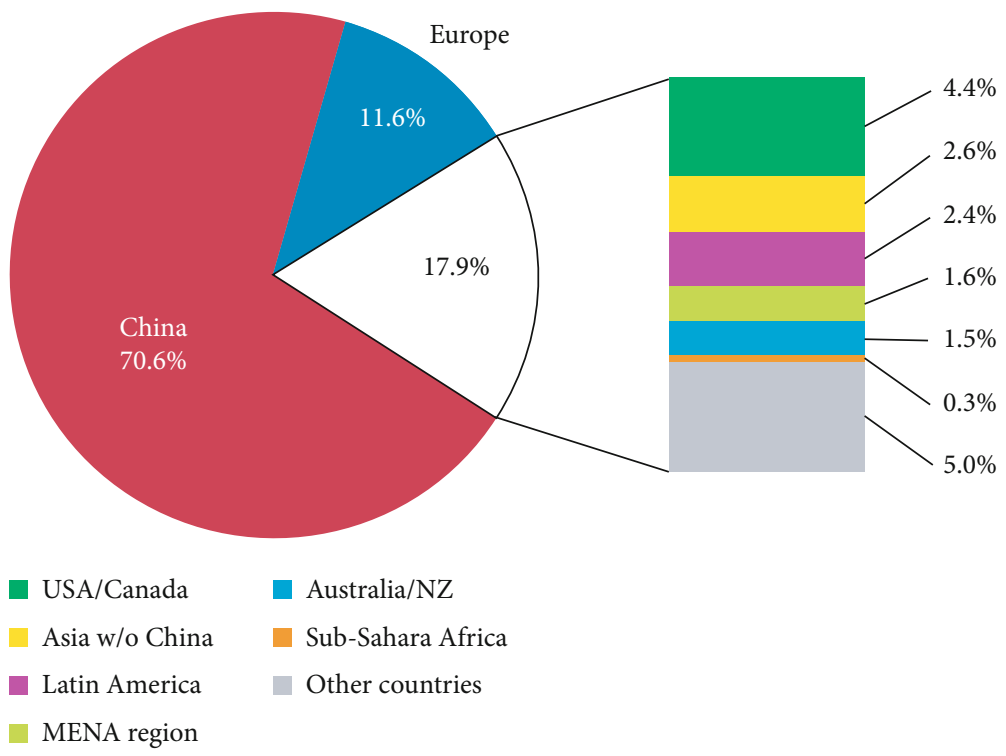

FIGURE 3: Share of the total installed capacity in operation (glazed and unglazed water and air collectors) by the economic region in 2014 [20, 21].

Zambia, on average, has 2000-3000 sunny hours during the year, with its 20-year average horizontal radiation power shown in Figure 4 [39], due to high initial costs of solar equipment, the solar market is not much popular in Zambia [40]. Investing opportunities in Zambia include local manufacturing of solar system elements, creation of an offgrid microgrid, and selling of solar panels and accessories to households [40].

Wind energy in Zambia is rather weak, and the average annual wind speed at $10 \mathrm{~m}$ in this country is $2.5 \mathrm{~m} / \mathrm{s}$. This low potential may be suitable for purposes such as water pumping at a domestic scale and irrigation, although there are reportedly some spots in western provinces with a wind speed up to $6 \mathrm{~m} / \mathrm{s}$ [37]. Regarding geothermal energy, it should be mentioned that there are more than 80 hot water springs in Zambia, 35 of which are suitable in terms of having a high temperature and being close to the main grid. Due to the high costs associated with geothermal plants, currently, there is only one small geothermal plant in Zambia built in the1980s. This plant has a development capacity of up to 2 MW [37]. The northern and northwestern parts of Zambia have a good potential in terms of small-scale hydropower plants. It is noteworthy that hydropower produces $97 \%$ of energy demand in Zambia and is the second important energy source in this country, following wood [41]. Currently, $2434.3 \mathrm{MW}$ of hydropower energy is developed in Zambia [37, 40].

Despite the aforementioned potentials for renewable energies, around $80 \%$ of heating demands (284 PJ) are supplied by traditional biomass which causes problems such as forest destruction and environmental pollution [42, 43]. These issues show the necessity of using SWHs for economic and social improvement. The summary of aspects regarding renewable energy potential in Zambia is presented in Table 1.

Despite the higher demands for electric energy in commercial, agricultural, and industrial sectors, power supply capacity has not changed significantly compared with the previous decade [27]. The national power utility ZESCO Ltd. has declared its plans to install 350000 SWHs for a $40 \%$ saving in the electricity demand caused by EWHs. This not only leads to lower costs but also reduced electricity imports. A three-year period was also estimated for capital recovery for SWHs' useful lifetime of 15 years [31, 34-36]. Currently, only 100 SWHs are installed in Lusaka and SWHs suffer from a stagnant market in Zambia. Factors leading to the lack of development of renewables in Zambia are lack of technical expertise, lack of capital, and the high-interest rate of loans which increase the foreign investment risks in Zambia [34-36].

In order to solve the technical expertise constraints, the paper analyzed various cities in order to determine SWH parameters, sizing, and its potential to reduce the energy demand and mitigate carbon emissions. The paper selected 22 cities from various provinces to enable us to determine the national thermal energy requirements. The required data for 22 cities that are used in TSOL Pro 5.5 are presented in Table 2, and the cities are shown in Figure 5. These data are extracted from the Meteonorm software which is installed as Meteosyn along with TSOL, and its function is to produce climate files. The location and geographical distribution of the studied cities are shown in Figure 5.

\section{The Simulation Software}

In studying the solar domestic hot water system performance, there is a need to use dynamic analysis tools to accurately describe the system responses to rapid changes in environmental conditions. TSOL Pro 5.5 is one of these tools, a professional simulation program for the design and planning of solar thermal systems [44]. It simulates and calculates the process in these systems by providing tools and components of solar systems and also the relevant components such as hot water 


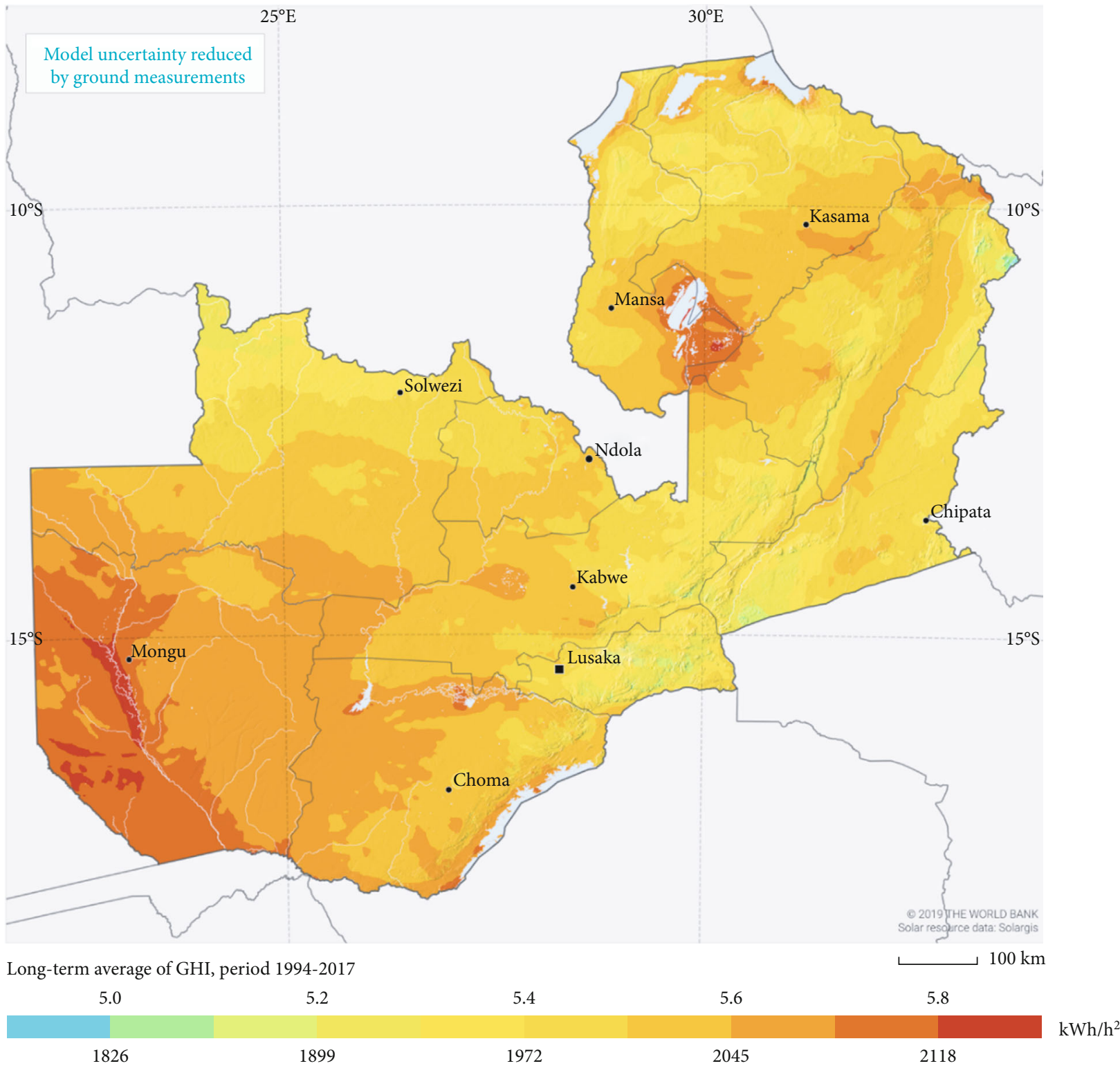

Figure 4: Global horizontal irradiation in Zambia [39].

TABLE 1: Renewable energy potential in Zambia.

\begin{tabular}{lcr}
\hline Renewable energy & Resource availability & Potential output \\
\hline Hydro & $\begin{array}{c}\text { Multiple mini and major sites across the cross; the country possesses } \\
\text { over } 40 \% \text { of water resources in the SADC region [45-47] }\end{array}$ & $6000 \mathrm{MW}$ \\
Biomass & 2.15 million tons [48] & A98 MW \\
Wind & Average $3 \mathrm{~m} / \mathrm{s}$ at $10 \mathrm{~m}$ height; hotspots in northern and & Not quantified \\
Geothermal & eastern regions [37] & Not quantified \\
Solar & 80 hot springs; 35 viable [49] & Not quantified \\
\hline
\end{tabular}

supply, swimming pool, heating process, and buffer tanks. This software enables the optimal design of solar thermal systems, temperature simulation, and their energy performance at lower cost and time [44]. In TSOL Pro 5.5, calculations are performed based on the balance of energy flows and provide yield prognoses according to the hourly meteorological data provided [44].

The total radiation received on a collector surface is a summation of direct and diffuse radiation. Direct radiation 
TABLE 2: The data of the studied cities.

\begin{tabular}{|c|c|c|c|c|}
\hline Station & Latitude & Longitude & Total annual global irradiation $\left(\mathrm{kWh} / \mathrm{m}^{2}\right)$ & Diffuse radiation percentage (\%) \\
\hline Chipata & -13.6 & -32.6 & 2089.1 & 46.5 \\
\hline Isoka & -10.1 & -32.6 & 2145.3 & 41.80 \\
\hline Choma & -16.8 & -27.1 & 2204.0 & 50.3 \\
\hline Kabompo & -13.6 & -24.2 & 2030.6 & 48 \\
\hline Kabwe & -14.5 & -28.5 & 2116.1 & 49.2 \\
\hline Kafironda & -12.6 & -28.1 & 1988.8 & 50.4 \\
\hline Kafue & -15.80 & -27.90 & 2073.3 & 47.80 \\
\hline Kasama & -10.20 & -31.10 & 2029.9 & 51.30 \\
\hline Kawambwa & -9.8 & -29.10 & 1922.3 & 53.20 \\
\hline Livingstone & -17.8 & -25.80 & 2276.2 & 50.70 \\
\hline Lusaka & -15.4 & -28.3 & 1989.4 & 50.20 \\
\hline Mansa & -11.1 & -28.9 & 1950.2 & 51.7 \\
\hline Mbala & -8.9 & -31.3 & 2225.9 & 48.1 \\
\hline Misamfu & -10.1 & -31.3 & 2040.0 & 50.60 \\
\hline Mongu & -15.2 & -23.1 & 2146.9 & 47.50 \\
\hline Mount Makulu & -15.6 & -28.3 & 1988.1 & 50.50 \\
\hline Mpika & -11.9 & -31.4 & 2047.8 & 50.70 \\
\hline Mwinilunga & -11.8 & -24.4 & 1943.5 & 51.6 \\
\hline Ndola & -13 & -28.70 & 2000.5 & 50.0 \\
\hline Sesheke & -17.5 & -24.3 & 2310.2 & 49.9 \\
\hline Solwezi & -12.2 & -26.4 & 1983.9 & 50.3 \\
\hline Zambezi & -13.5 & -23.1 & 2005.7 & 49.7 \\
\hline
\end{tabular}

is available in the supplied climate files, and the calculations of diffuse radiation striking the collector surface are performed using $\alpha$ angle and hourly clearness index $k_{\mathrm{t}}$ according to the following relations [44]:

$$
\begin{gathered}
0 \leq k_{\mathrm{t}} \leq 0.3: \frac{I_{\mathrm{d}}}{I}=1.02-0.245 k_{\mathrm{t}}+0.0123 \sin \alpha \\
0.3<k_{\mathrm{t}} \leq 0.78: \frac{I_{\mathrm{d}}}{I}=1.4-1.749 k_{\mathrm{t}}+0.177 \sin \alpha \\
k_{\mathrm{t}} \geq 0.78: \frac{I_{\mathrm{d}}}{I}=0.486 k_{\mathrm{t}}-0.182 \sin \alpha
\end{gathered}
$$

where $I$ is the total hourly radiation on a horizontal surface $\left(\mathrm{kJ} / \mathrm{m}^{2}\right)$ and $I_{\mathrm{d}}$ is the hourly diffuse radiation on a horizontal surface $\left(\mathrm{kJ} / \mathrm{m}^{2}\right)$. It is noteworthy that some incident radiation on the collector surface is wasted. The software calculates collector losses by [44]

$$
\begin{aligned}
\rho= & G_{\mathrm{dir}} \cdot \eta_{0} \cdot f_{\text {IAM }}+G_{\text {diff }} \cdot \eta_{0} \cdot f_{\text {IAM.diff }} \\
& -k_{0}\left(T_{\mathrm{cm}}-T_{\mathrm{A}}\right)-k_{\mathrm{q}}\left(T_{\mathrm{cm}}-T_{\mathrm{A}}\right)^{2},
\end{aligned}
$$

where $G_{\text {dir }}$ is the part of solar radiation striking a tilted surface, $\eta_{0}$ is the collector's zero-loss efficiency, $f_{\text {IAM }}$ is the incidence angle modifier factor, $G_{\text {diff }}$ is the diffuse solar radiation striking a tilted surface, $f_{\text {IAM,diff }}$ is the diffuse incidence angle modifier factor, $k_{0}$ is the heat transfer coefficient (in $\left.\mathrm{W} / \mathrm{m}^{2} \cdot \mathrm{k}\right), T_{\mathrm{cm}}$ is the average temperature of the collector,
$T_{\mathrm{A}}$ is the air temperature, and $k_{\mathrm{q}}$ is the heat transfer coefficient (in $\mathrm{W} / \mathrm{m}^{2} \cdot \mathrm{k}^{2}$ ).

The software considers the solar system's $\mathrm{CO}_{2}$ emission savings of $5.14355 \mathrm{~g}$ per $\mathrm{kJ}$ of energy generated [44]. The energy supplied by collectors is obtained by dividing the energy transferred from the solar system to the standby tank by the total energy supply of the standby tank (solar system + auxiliary heating) according to the following relation [44]:

Solar fraction total $=\frac{Q_{\text {CL.DHW }}+Q_{\text {S.HL }}}{Q_{\text {CL.DHW }}+Q_{\text {S.HL }}+Q_{\text {AuxH.DHW }}+Q_{\text {AuxH.HL }}}$.

Other relations used in simulations, shown schematically in Figure 6, are as follows [44]:

$$
\begin{aligned}
\text { Solar fraction DHW } & =\frac{Q_{\text {CL.DHW }}}{Q_{\text {CL.DHW }}+Q_{\text {AuxH.DHW }}}, \\
\text { Solar fraction heating } & =\frac{Q_{\text {S.HL }}}{Q_{\text {S.HL }}+Q_{\text {AuxH.HL }}} .
\end{aligned}
$$

\section{Simulation Data Input}

Information on the geographical position, diffuse radiation percentage, and total annual global radiation for the analyzed cities is presented in Table 2. These cities are also shown in Figure 5. The average daily sanitary hot water consumption of $110 \mathrm{~L}$, the sanitary hot water temperature of $60^{\circ} \mathrm{C}$, and 


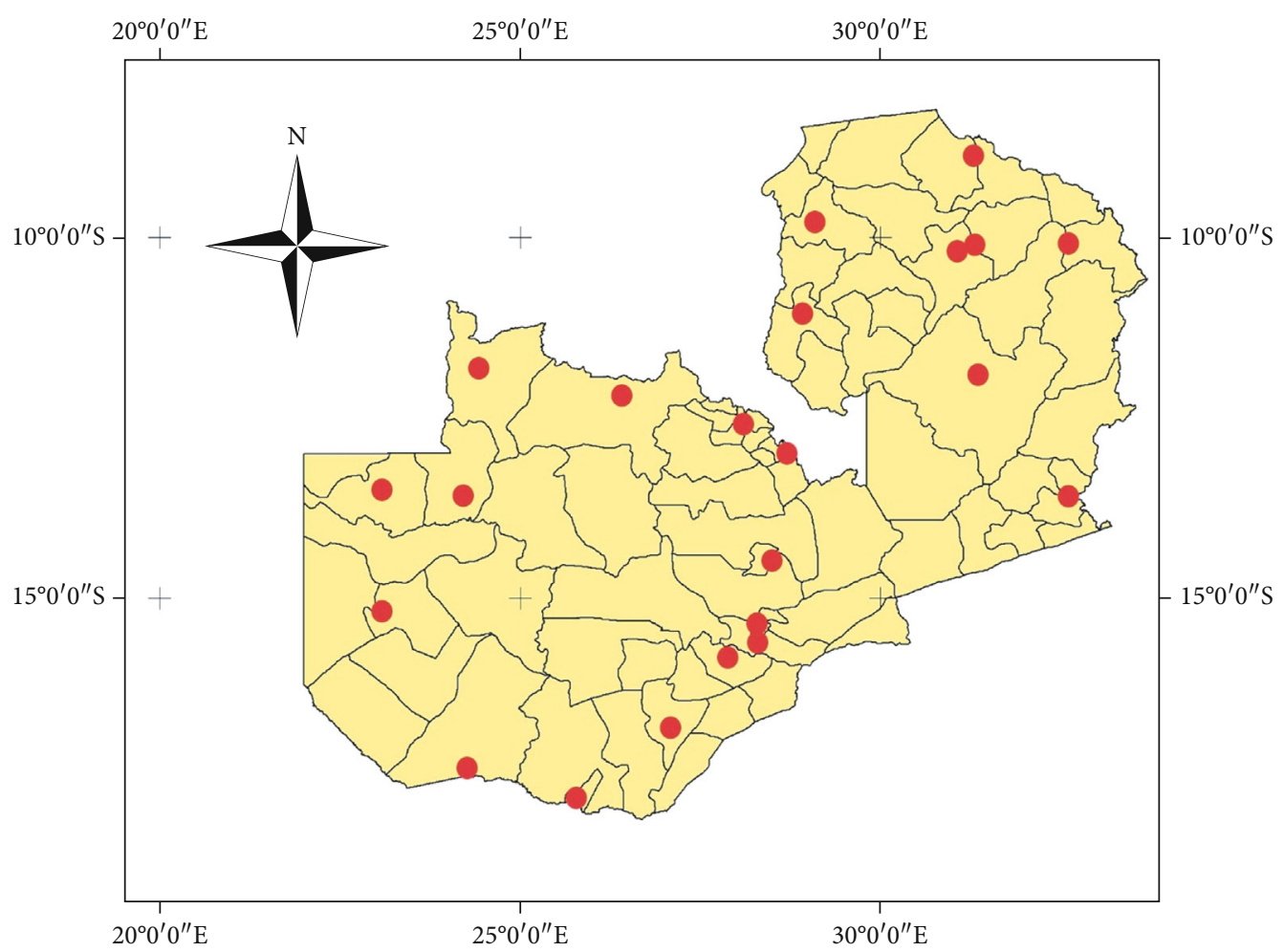

FIGURE 5: The location of studied cities.

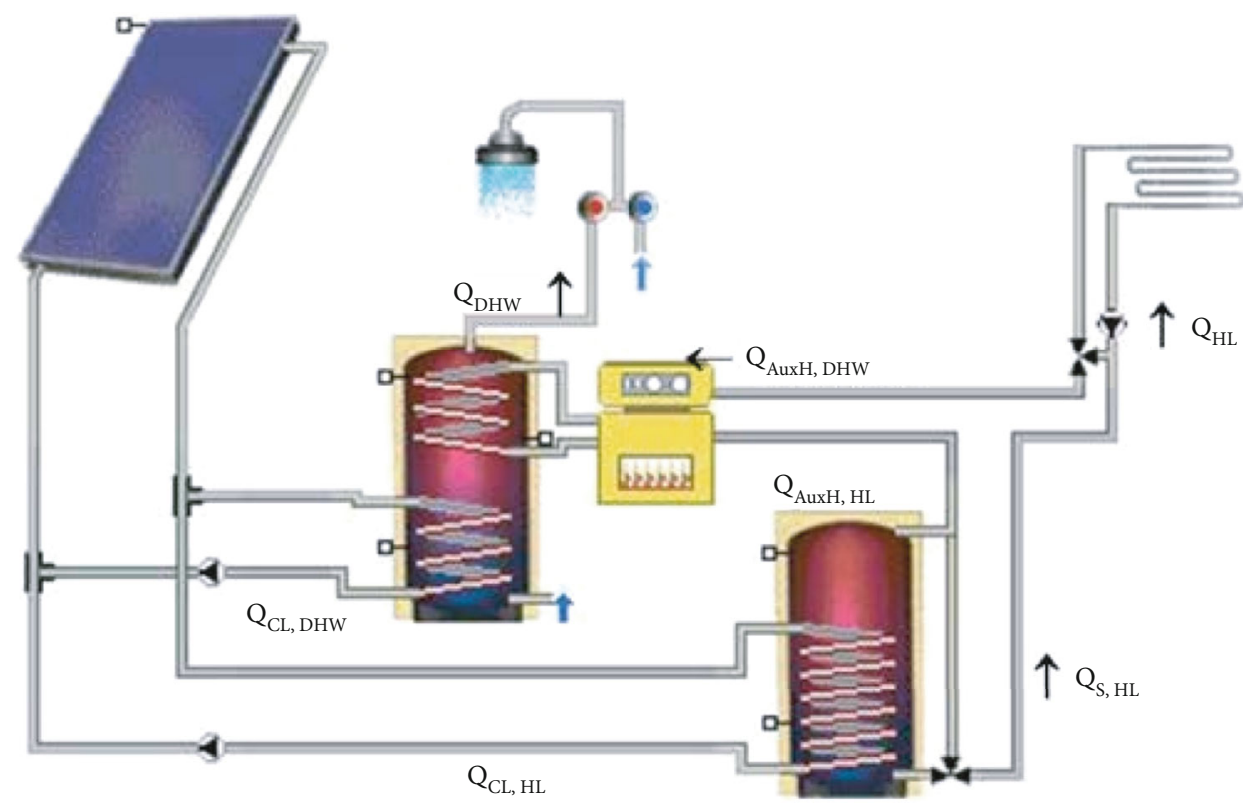

FIGURE 6: Schematic of the solar system with a bivalent storage tank (internal heat exchanger). DHW: domestic hot water; S,HL: solar heating load; HL: heating load; AuxH: auxiliary heating; CL: collector loop.

operating period of the whole year are assumed. Furthermore, the assumed space heating load of $10 \mathrm{~kW}$, space temperature of $21^{\circ} \mathrm{C}$, and heated usable area of $80 \mathrm{~m}^{2}$ are used. Double-glazed windows with an area of $1.6,4,8$, and $5.6 \mathrm{~m}^{2}$ are considered for north-, east-, south-, and west-facing windows, respectively. $5 \mathrm{~W} / \mathrm{m}^{2}$ heat gain due to internal heat sources is also considered. On the other hand, the heating load requirements of the building were assumed as constant throughout the year (except June and July) from 23:00 up to $06: 00$. An average wall type value is considered in this paper. Another assumption is done on SWH and other accessory equipment such as buffer tanks, piping, and boiler that are installed in all the selected cities to enable us to compare the heat generation characteristics and energy potential. In 


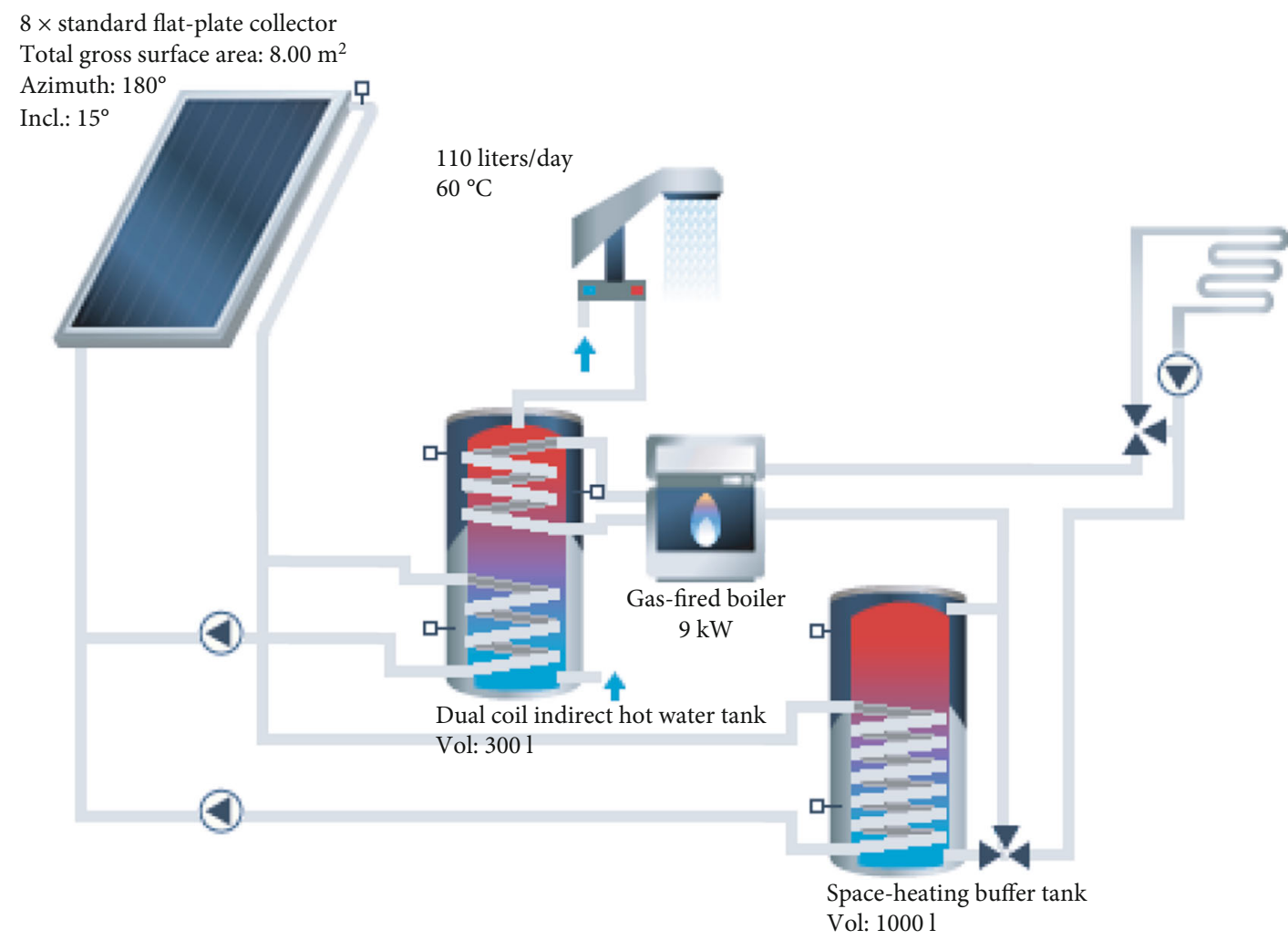

FIgURE 7: The specifications and components of the simulated system.

this model, a standard flat-plate-type SWH with an area of 8 $\mathrm{m}^{2}$ and $0^{\circ}$ azimuth angle is used. Double-coil buffer tanks for sanitary hot water and space heating are used having $300 \mathrm{~L}$ and $1000 \mathrm{~L}$ capacities, respectively (as shown in Figure 7). Also, a gas boiler with a rated capacity of $9 \mathrm{~kW}$ was utilized. Water/polypropylene glycol in a 60/40 ratio and a rate of $40 \mathrm{~L} / \mathrm{m}^{2}$ was used as the intermediate heat transfer fluid. In the case of high requirement for space heating, in/outlet temperature difference of $20^{\circ} \mathrm{C}$ and that for other cases $15^{\circ} \mathrm{C}$ are considered. The general schematic of the simulated system is shown in Figure 7. It should be noted that the solar panels' tilt angle was equal to the latitude of the studied area [44].

\section{Results}

Analysis results for 22 cities are summarized in Table 3. According to the results, it could be seen that Sesheke, Livingstone, and Mongu cities by supplying, respectively, $99.2 \%, 98.6 \%$, and $95.4 \%$ of their heating demands through SWHs, are the most suitable stations.

Three cities Livingstone (100\% supply of the required energy), Sesheke (99.7\% supply of the required energy), and Mount Makulu (85.4\% supply of required energy) have the highest percentage of solar space heating for buildings in Zambia. Regarding the supply of space heating, Mbala, Misamfu, and Kasama stations take the first to third ranks by supplying $1564.57 \mathrm{kWh}, 1212.59 \mathrm{kWh}$, and $1090.35 \mathrm{kWh}$ of space heating by SWHs. However, since their heating demands are higher, they are not among the top three cities in terms of the highest space heating using SWHs.
In terms of sanitary hot water, three cities Mbala, Isoka, and Solwezi are in the first to third positions by producing $2649.87 \mathrm{kWh}, 2646 \mathrm{kWh}$, and $2605.93 \mathrm{kWh}$ of sanitary hot water, respectively, although it should be mentioned that Sesheke, Livingstone, and Isoka cities are the three superior cities by producing, respectively, $99.1 \%, 98.5 \%$, and $98.4 \%$ of their hot water demand by SWHs.

According to the saving in GHG emissions due to fossil fuels, the three cities Kabwe, Chipata, and Mbala are the top three cities by saving $1552.97 \mathrm{~kg} / \mathrm{y}, 1394.8 \mathrm{~kg} / \mathrm{y}$, and $1321.39 \mathrm{~kg} / \mathrm{y}$, respectively. Also, regarding the use of a boiler for supplying the remaining demand for space heating and hot water consumption, it could be said that SWHs provide $62.47 \%$ of space heating and $96.05 \%$ of sanitary hot water demands. This shows a clear justification for using SWHs to supply sanitary hot water compared with space heating demands. To sum up, it can be concluded that the most suitable cities in terms of providing space heating, sanitary hot water, and simultaneous space heating and sanitary hot water using SWHs are Livingstone (100\% of required energy), Sesheke (99.1\% of required energy), and Sesheke $(99.2 \%$ of required energy) cities.

Sesheke shows the most attractiveness in investing in SWHs which, according to the results in Table 2, has a high annual average radiation and low diffuse radiation. Figures 8 and 9 show the share of solar energy in the total energy requirement and the schematic of energy balance for Sesheke Town.

From Figure 8, it could be seen that in 10 months of the year (except for December and February), almost all the 
TABLE 3: The results of the studied parameters per town/city.

\begin{tabular}{|c|c|c|c|c|c|c|c|c|c|}
\hline Station & $\begin{array}{c}\text { Total } \\
\text { solar } \\
\text { fraction } \\
(\%)\end{array}$ & $\begin{array}{l}\text { Solar } \\
\text { contribution to } \\
\text { heating }(\mathrm{kWh})\end{array}$ & $\begin{array}{l}\text { Heating } \\
\text { solar } \\
\text { fraction } \\
(\%)\end{array}$ & $\begin{array}{c}\text { Solar } \\
\text { contribution } \\
\text { to DHW } \\
(\mathrm{kWh})\end{array}$ & $\begin{array}{l}\text { DHW } \\
\text { solar } \\
\text { fraction } \\
(\%)\end{array}$ & $\begin{array}{c}\text { Saving } \\
\text { natural gas } \\
(\mathrm{H})\left(\mathrm{m}^{3}\right)\end{array}$ & $\begin{array}{c}\mathrm{CO}_{2} \\
\text { emissions } \\
\text { avoided } \\
(\mathrm{kg})\end{array}$ & $\begin{array}{c}\text { Boiler energy } \\
\text { to heating } \\
(\mathrm{kWh})\end{array}$ & $\begin{array}{c}\text { Boiler } \\
\text { energy to } \\
\text { DHW } \\
(\mathrm{kWh})\end{array}$ \\
\hline Chipata & 83.6 & 416.32 & 44.1 & 2488.50 & 95.3 & 659.6 & 1394.80 & 527 & 121 \\
\hline Isoka & 84.9 & 739.08 & 56.9 & 2646.00 & 98.4 & 543.4 & 1149.03 & 559 & 43 \\
\hline Choma & 92.7 & 489.26 & 74.5 & 2526.18 & 97.3 & 495.2 & 1047.07 & 168 & 71 \\
\hline Kabompo & 86.4 & 807.93 & 65.0 & 2518.93 & 96.6 & 528.2 & 1116.52 & 435 & 87 \\
\hline Kabwe & 81.7 & 927.28 & 57.4 & 2549.07 & 96.7 & 545.2 & 1552.97 & 689 & 87 \\
\hline Kafironda & 80.2 & 733.25 & 52.3 & 2472.34 & 95.3 & 511.0 & 1080.58 & 669 & 123 \\
\hline Kafue & 82.4 & 792.5 & 55.7 & 2537.99 & 96.9 & 528.7 & 1117.99 & 631 & 82 \\
\hline Kasama & 71.3 & 1090.35 & 45.6 & 2490.00 & 94.6 & 550.0 & 1163.11 & 1301 & 142 \\
\hline Kawambwa & 74.6 & 748.78 & 44.2 & 2448.25 & 94.4 & 505.6 & 1069.19 & 945 & 146 \\
\hline Livingstone & 98.6 & 187.11 & 100 & 2485.94 & 98.5 & 454.8 & 961.81 & 0 & 37 \\
\hline Lusaka & 77.8 & 873.64 & 51.3 & 2474.32 & 95.1 & 525.6 & 525.6 & 829 & 129 \\
\hline Mansa & 74.7 & 763.33 & 45.4 & 2422.34 & 93.8 & 503.9 & 1065.61 & 918 & 161 \\
\hline Mbala & 62.6 & 1564.57 & 39.1 & 2649.87 & 97.0 & 624.9 & 1321.39 & 2433 & 82 \\
\hline Misamfu & 73.7 & 1212.59 & 51.0 & 2492.64 & 94.1 & 564.7 & 1194.08 & 1167 & 158 \\
\hline Mongu & 95.4 & 369.43 & 81.8 & 2496.54 & 97.8 & 477.4 & 1009.62 & 85 & 55 \\
\hline $\begin{array}{l}\text { Mount } \\
\text { Makulu }\end{array}$ & 93.5 & 489.03 & 85.4 & 2481.92 & 95.3 & 486.1 & 1027.85 & 84 & 122 \\
\hline Mpika & 91.3 & 549.70 & 79.2 & 2514.71 & 94.5 & 497.2 & 1051.36 & 144 & 146 \\
\hline Mwinilunga & 74.2 & 959.71 & 47.4 & 2490.29 & 94.8 & 534.2 & 1129.53 & 1066 & 136 \\
\hline Ndola & 79.9 & 938.09 & 56.7 & 2458.26 & 94.6 & 530.2 & 1121.16 & 716 & 140 \\
\hline Sesheke & 99.2 & 200.38 & 99.7 & 2503.47 & 99.1 & 459.4 & 971.50 & 0.64 & 22 \\
\hline Solwezi & 93.0 & 553.71 & 76.6 & 2605.93 & 97.5 & 513.3 & 1085.44 & 169 & 68 \\
\hline Zambezi & 85.5 & 818.53 & 64.9 & 2491.96 & 95.4 & 524.0 & 1108.01 & 442 & 119 \\
\hline
\end{tabular}

DHW: domestic hot water.

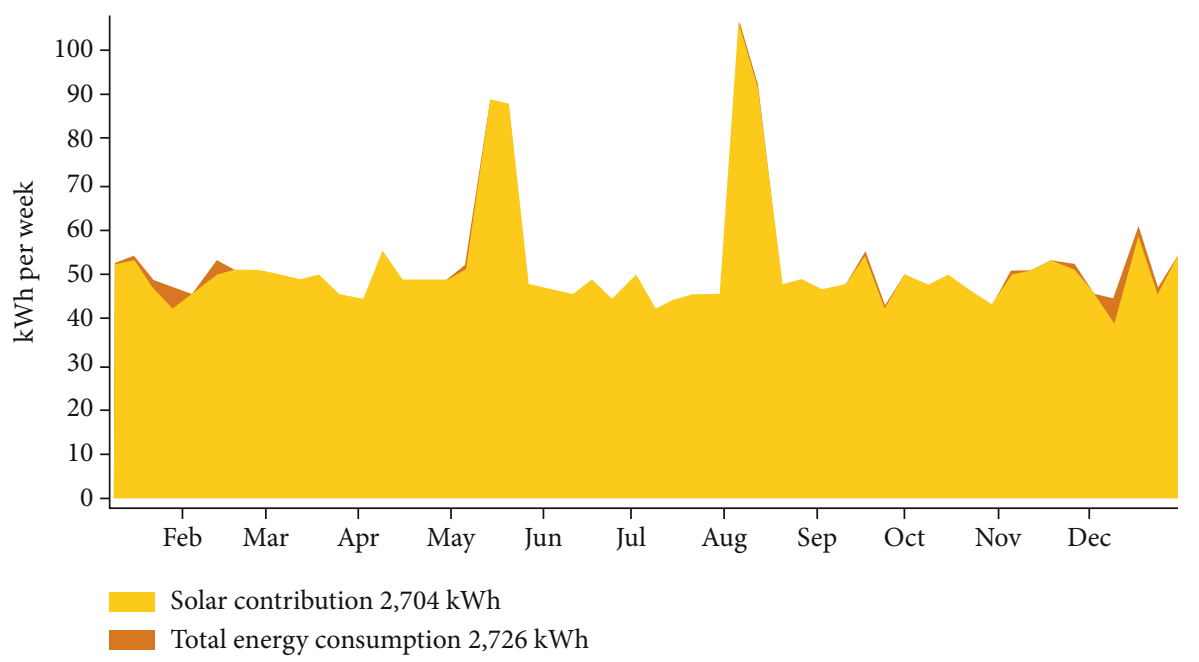

FIGURE 8: Solar energy consumption as a percentage of total consumption for Sesheke Town.

required energies are provided by solar collectors. According to Figure 8, the boiler is most needed in December and February during which collectors can provide $97 \%$ and $96 \%$ of heating demands, respectively.
The schematic view of the energy balance for Sesheke Town is shown in Figure 9. It illustrates that the radiation on the surface of solar collectors is $19377 \mathrm{kWh}$. Figure $9 \mathrm{dem}-$ onstrates that most of the losses are thermal and then optical 


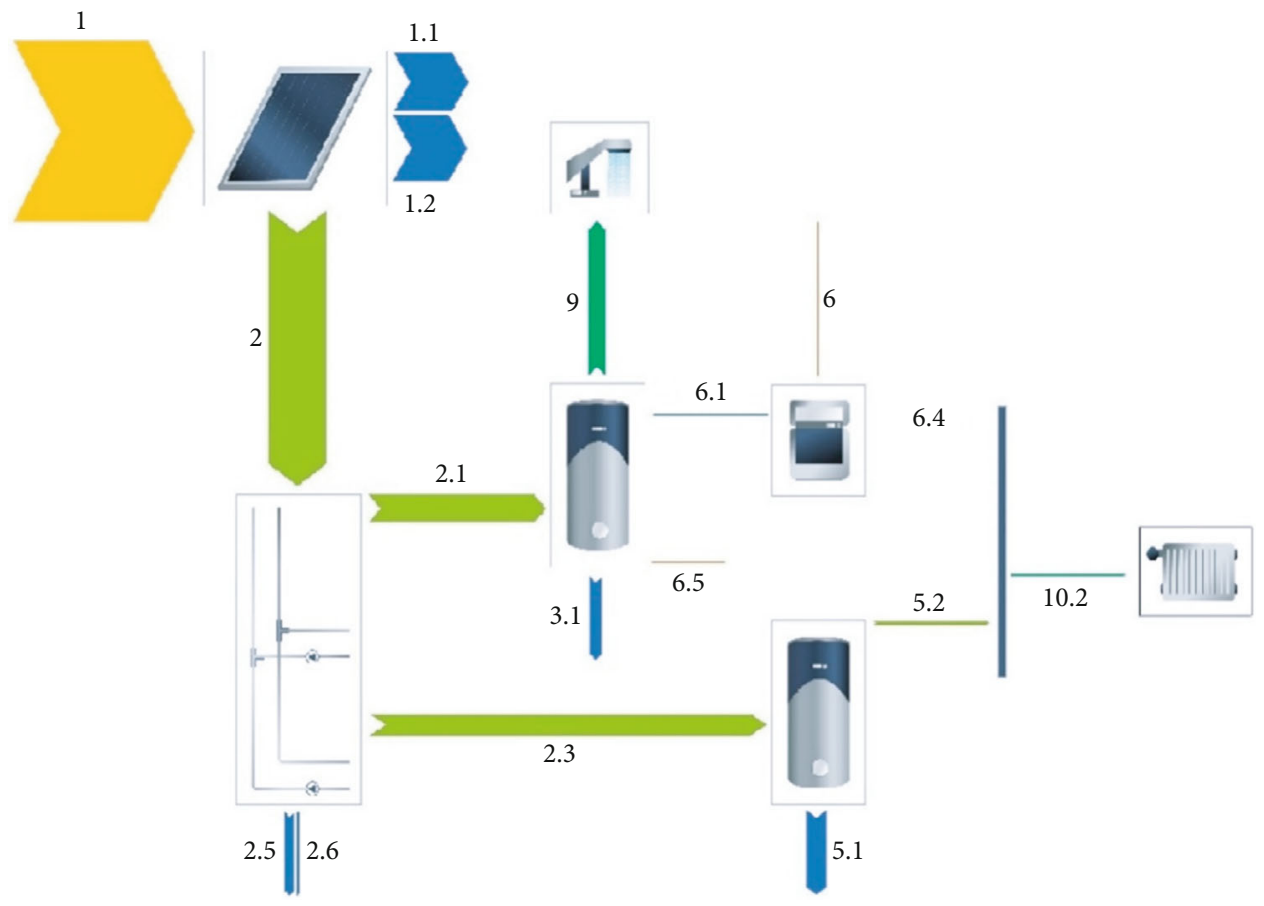

\begin{tabular}{llr}
1 & Irradiation on to collector surface (active) & $19,377 \mathrm{kWh}$ \\
1.1 & Optical collector losses & $6,166 \mathrm{kWh}$ \\
\hline 1.2 & Thermal collector losses & $7,065 \mathrm{kWh}$ \\
\hline 2 & Energy from collector array & $6,146 \mathrm{kWh}$ \\
\hline 2.1 & Solar energy to storage tank & $2,982 \mathrm{kWh}$ \\
\hline 2.3 & Solar energy to buffer tank & $2,113 \mathrm{kWh}$ \\
2.5 & Internal piping losses & $935 \mathrm{kWh}$ \\
\hline 2.6 & External piping losses & $118 \mathrm{kWh}$ \\
3.1 & Tank losses & $1,347 \mathrm{kWh}$ \\
\hline 5.1 & Buffer tank losses & $1,906 \mathrm{kWh}$ \\
5.2 & Buffer tank to heating & $201 \mathrm{kWh}$ \\
\hline 6 & Final energy & $35 \mathrm{kWh}$ \\
6.1 & Supplementary energy to tank & $19 \mathrm{kWh}$ \\
\hline 6.4 & Supplementary energy to space-heating & $0 \mathrm{kWh}$ \\
6.5 & Electric element & $0 \mathrm{kWh}$ \\
\hline 9 & DHW energy from tank & $1,652 \mathrm{kWh}$ \\
10.2 & Heat to LT heating & $201 \mathrm{kWh}$
\end{tabular}

Figure 9: Energy balance schematic for Sesheke Town. DHW: domestic hot water; LT: low temperature.

losses. In the next ranks, most losses occur in the buffer tank, main tank, internal piping, and external piping, respectively. It is obvious that energy losses in the piping system are low, and almost $18.5 \%$ of energy loss (3253 kWh) occurs in tanks. This energy loss in tanks depends on the tank geometry and target values. Due attention should be given to minimize these energy losses through planning and scientific initiatives for each specific scenario.

Comparing the results of the present work with the works reviewed in the literature review, it can be seen that in recent studies in all parts of the world, the potential for sanitary hot water supply is very high and the main difference in the results is regarding the heat supply for space heating. Among the studies, the lowest percentage of heat supply required for space heating is related to Canada, where flat-panel solar water heaters have been able to provide $25 \%$ of the required heat at best [29].

\section{Implications and Limitations}

For the first time, the present study examines the potential of Zambia's various stations in the technical, energy, and environmental fields. The results could serve as a roadmap for energy policymakers in Zambia and suggest the best station for starting investment. This could lead to the economic and social development of Zambia, provided that the right policies are implemented in this regard.

Regarding the limitations of the present work, it can be pointed out that the climatic data used (extracted from the Meteosyn software) are an average of several years and are 
not related to one year. It is not possible to specify the exact details of the windows and walls of the building under study in the software. The type of auxiliary boilers and solar collectors available in the software database is limited. Also, the space can be heated only by the radiator.

\section{Conclusion}

The study is aimed at reducing energy consumption in Zambia and encouraging people to use a solar renewable energy source for residential space heating and sanitary hot water purposes. Also, minimizing the expenditures and improving the welfare of low-income households, especially in remote areas, by providing them with the best optimal choice on SWHs best fit for their dwelling. The simulations on solar data of 22 cities are performed using TSOL Pro 5.5. The results show the following:

(i) Producing $100 \%$ of space heating demands, Livingstone recorded the highest percentage of supplying thermal energy for a building in Zambia

(ii) Sesheke is the most suitable station in terms of producing hot water by supplying $99.1 \%$ of its requirements through SWHs

(iii) Regarding GHG emission due to fossil fuels, the Kabwe station is the town with the highest greenhouse gas emission reduction, and it showed a saving of $1552.97 \mathrm{~kg} / \mathrm{y}$ in $\mathrm{CO}_{2}$ pollutants

(iv) SWHs can supply $62.47 \%$ of space heating demands and $96.05 \%$ of sanitary hot water requirements

(v) Generally, the best town in terms of simultaneous provision of space heating and hot water using SWHs is found to be Sesheke by producing $99.2 \%$ of required energy

These findings are the key to policymakers and investors in arriving at the investment decision as well as for the building owners to make the cost-effective choices of technology in hot water and space heating in Zambia. This paper does not investigate the government's impact if rebates and incentives are introduced to promote an increase in penetration of SWHs; however, it is strongly recommended that such anal$y$ sis is done in the near future.

\section{Nomenclature}

$k_{\mathrm{t}}: \quad$ Hourly clearness index

I: $\quad$ Total hourly radiation on a horizontal surface $\left(\mathrm{kJ} / \mathrm{m}^{2}\right)$

$I_{\mathrm{d}}$ : $\quad$ Hourly diffuse radiation on a horizontal surface $\left(\mathrm{kJ} / \mathrm{m}^{2}\right)$

$G_{\text {dir }}$ : $\quad$ Part of solar radiation striking a tilted surface

$\eta_{0}: \quad$ Collector's zero-loss efficiency

$f_{\text {IAM }}$ : Incidence angle modifier factor

$G_{\text {diff }}$ : Diffuse solar radiation striking a tilted surface

$f_{\text {IAM,diff }}:$ Diffuse incidence angle modifier factor

$k_{0}: \quad$ Heat transfer coefficient $\left(\mathrm{W} / \mathrm{m}^{2} \cdot \mathrm{k}\right)$

$\begin{array}{ll}\alpha: & \text { Tilt angle } \\ \rho: & \text { Collector losses } \\ \mathrm{LT}: & \text { Low temperature } \\ T_{\mathrm{A}}: & \text { Air temperature } \\ T_{\mathrm{cm}}: & \text { Average temperature of the collector } \\ k_{\mathrm{q}}: & \text { Heat transfer coefficient }\left(\mathrm{W} / \mathrm{m}^{2} \cdot \mathrm{k}^{2}\right) \\ Q_{\mathrm{CL} ; \mathrm{DHW}}: & \text { Collector loop heating for domestic hot water } \\ \mathrm{Q}_{\mathrm{S}, \mathrm{HL}}: & \text { Solar heating for heating load } \\ Q_{\mathrm{Aux}, \mathrm{DHW}}: & \text { Auxiliary heating for domestic hot water } \\ Q_{\mathrm{Aux}, \mathrm{HHL}}: & \text { Auxiliary heating for heating load } \\ \text { EWH: } & \text { Electric water heater } \\ \mathrm{SWH}: & \text { Solar water heater } \\ \mathrm{DHW}: & \text { Domestic hot water } \\ \text { REFIT: } & \text { Renewable energy feed-in tariff } \\ \mathrm{GHG}: & \text { Greenhouse gases. }\end{array}$

\section{Data Availability}

All data used to support the findings of this study are included within the article.

\section{Conflicts of Interest}

The authors declare that they have no conflicts of interest.

\section{References}

[1] S. Jahangiri Mamouri and A. Bénard, "New design approach and implementation of solar water heaters: a case study in Michigan," SolarEnergy, vol. 162, pp. 165-177, 2018.

[2] J. D. Kelso, Buildings Energy Data Book, US department of energy, 2009.

[3] U. DOE, Buildings Energy Data Book, US department of energy, D\&R International, Ltd, Silver Spring, Maryland, 2014.

[4] X. Zhai, R. Wang, Y. Dai, J. Wu, Y. Xu, and Q. Ma, "Solar integrated energy system for a green building," Energy and Buildings, vol. 39, no. 8, pp. 985-993, 2007.

[5] P. A. F. Ferrer, "Average economic performance of solar water heaters for low density dwellings across South Africa," Renewableand Sustainable Energy Reviews, vol. 76, pp. 507-515, 2017.

[6] A. H. H. Ali, "Performance-cost and global warming assessments of two residential scale solar cooling systems versus a conventional one in hot arid areas," Sustainable Energy Technologies and Assessments, vol. 20, pp. 1-8, 2017.

[7] K. C. Chang, W. M. Lin, and K. M. Chung, "Solar water heaters as a pre-heating system for industrial processes," Energy Efficiency, vol. 11, no. 3, pp. 755-760, 2018.

[8] J. Maguire, X. Fang, and E. Wilson, "Comparison of advanced residential water heating technologies in the United States," Contract, vol. 303, pp. 275-3000, 2013.

[9] A. Gautam, S. Chamoli, A. Kumar, and S. Singh, "A review on technical improvements, economic feasibility and world scenario of solar water heating system," Renewable and Sustainable Energy Reviews, vol. 68, pp. 541-562, 2017.

[10] S. M. Sichilalu and X. Xia, "Optimal power dispatch of a grid tied-battery-photovoltaic system supplying heat pump water heaters," Energy Conversion and Management, vol. 102, pp. 81-91, 2015. 
[11] F. Wamalwa, S. M. Sichilalu, and X. Xia, "Optimal energy mix of a microhydro-wind-grid system powering a dairy farm in Western Cape, South Africa," Energy Procedia, vol. 142, pp. 708-715, 2017.

[12] E. M. Wanjiru, S. M. Sichilalu, and X. Xia, "Optimal control of heat pump water heater-instantaneous shower using integrated renewable-grid energy systems," Applied Energy, vol. 201, pp. 332-342, 2017.

[13] D. Mills, "Advances in solar thermal electricity technology," Solar Energy, vol. 76, no. 1-3, pp. 19-31, 2004.

[14] T. Roulleau and C. Lloyd, "International policy issues regarding solar water heating, with a focus on new Zealand," Energy Policy, vol. 36, no. 6, pp. 1843-1857, 2008.

[15] S. H. Abu-Bakar, F. Muhammad-Sukki, R. Ramirez-Iniguez et al., "Financial analysis on the proposed renewable heat incentive for residential houses in the United Kingdom: a case study on the solar thermal system," Energy Policy, vol. 65, pp. 552-561, 2014.

[16] Ofgem, “Domestic Renewable Heat Incentive," 2018, https:// www.ofgem.gov.uk/environmental-programmes/domesticrenewable-heat-incentive.

[17] A. Estif, "Solar thermal strategy: sun in action ii," Renewable Energy World, vol. 2, pp. 200-209, 2003.

[18] F. Mauthner, W. Weiss, and M. Spörk-Dür, "Solar heat worldwide: markets and contribution to the energy supply 2012," International Energy Agency-Solar Heating and Cooling Program, vol. 2012, 2012.

[19] K. C. van Blommestein and T. U. Daim, "Residential energy efficient device adoption in South Africa," Sustainable Energy Technologies and Assessments, vol. 1, pp. 13-27, 2013.

[20] T. C. Kandpal and L. Broman, "Renewable energy education: a global status review," Renewable and Sustainable Energy Reviews, vol. 34, pp. 300-324, 2014.

[21] K. Kaygusuz, "Energy for sustainable development: a case of developing countries," Renewable and Sustainable Energy Reviews, vol. 16, no. 2, pp. 1116-1126, 2012.

[22] H. Benli, "Potential application of solar water heaters for hot water production in Turkey," Renewable and Sustainable Energy Reviews, vol. 54, pp. 99-109, 2016.

[23] P. Hohne, K. Kusakana, and B. Numbi, "Optimal energy management and economic analysis of a grid-connected hybrid solar water heating system: a case of Bloemfontein, South Africa," Sustainable Energy Technologies and Assessments, vol. 31, pp. 273-291, 2019.

[24] A. I. Bakry, Y. A. F. el-Samadony, S. A. el-Agouz, A. Alshrombably, K. Abdelfatah, and M. Said, "Performance of the one-ended evacuated tubes as medium temperature solar air heaters at low flow rates," Sustainable Energy Technologies and Assessments, vol. 30, pp. 174-182, 2018.

[25] S. Sichilalu and X. Xia, "Optimal power control of grid tied PV-battery-diesel system powering heat pump water heaters," Energy Procedia, vol. 75, pp. 1514-1521, 2015.

[26] M. Baneshi and S. A. Bahreini, "Impacts of hot water consumption pattern on optimum sizing and techno-economic aspects of residential hybrid solar water heating systems," Sustainable Energy Technologies and Assessments, vol. 30, pp. 139-149, 2018.

[27] K. Bowa, M. Mwanza, M. Sumbwanyambe, and J. Pretorius, "Solar photovoltaic energy progress in Zambia: a review," in Southern African Universities Power Engineering Conference, pp. 470-475, Stellenbosch, South Africa, 2017.
[28] S. Pahlavan, M. Jahangiri, A. AlidadiShamsabadi, and A. Khechekhouche, "Feasibility study of solar water heaters in Algeria, a review," Journal of Solar Energy Research, vol. 3, no. 2, pp. 135-146, 2018.

[29] M. Jahangiri, A. AlidadiShamsabadi, and H. Saghaei, "Comprehensive evaluation of using solar water heater on a household scale in Canada," Journal of Renewable Energy and Environment, vol. 5, no. 1, pp. 35-42, 2018.

[30] L. Siampour, S. Vahdatpour, M. Jahangiri et al., “Technoenviro assessment and ranking of Turkey for use of homescale solar water heaters," Sustainable Energy Technologies and Assessments, vol. 43, 2021.

[31] C. Artur, D. Neves, B. C. Cuamba, and A. J. Leão, “Comparison of two dynamic approaches to modelling solar thermal systems for domestic hot water," Sustainable Energy Technologies and Assessments, vol. 30, pp. 292-303, 2018.

[32] D. Kimemia, C. Vermaak, S. Pachauri, and B. Rhodes, "Burns, scalds and poisonings from household energy use in South Africa: are the energy poor at greater risk?," Energy for Sustainable Development, vol. 18, pp. 1-8, 2014.

[33] M. R. Assari, H. Basirat Tabrizi, and M. Savadkohy, "Numerical and experimental study of inlet-outlet locations effect in horizontal storage tank of solar water heater," Sustainable Energy Technologies and Assessments, vol. 25, pp. 181-190, 2018.

[34] M. McPherson, M. Ismail, D. Hoornweg, and M. Metcalfe, "Planning for variable renewable energy and electric vehicle integration under varying degrees of decentralization: a case study in Lusaka, Zambia," Energy, vol. 151, pp. 332-346, 2018.

[35] S. Mandelli, J. Barbieri, L. Mattarolo, and E. Colombo, "Sustainable energy in Africa: a comprehensive data and policies review," Renewable and Sustainable Energy Reviews, vol. 37, pp. 656-686, 2014.

[36] J. L. Sawin, V. S. O’Brien, A. McCrone et al., "Renewables 2010 Global Status Report," Renewable Energy Policy Network for the 21st Century (REN 21), Paris, 2010.

[37] P. Kachapulula-Mudenda, L. Makashini, A. Malama, and H. Abanda, "Review of renewable energy technologies in Zambian households: capacities and barriers affecting successful deployment," Buildings, vol. 8, no. 6, p. 77, 2018.

[38] O. Mfune and E. K. Boon, "Promoting renewable energy technologies for rural development in Africa: experiences of Zambia," Journal of Human Ecology, vol. 24, no. 3, pp. 175-189, 2008.

[39] Global Solar Atlas2018, http://globalsolaratlas.info/ downloads/zambia.

[40] Zambia development agency, "Promoting Zambia’s economic growth and development, Energy Sector Profile 2014," 2018, http://www.zda.org.zm.

[41] M. Gustavsson and A. Ellegård, "The impact of solar home systems on rural livelihoods. Experiences from the Nyimba Energy Service Company in Zambia," Renewable Energy, vol. 29, no. 7, pp. 1059-1072, 2004.

[42] S. Sichilalu, P. Lyandenga, H. Tazvinga et al., "Experimental determination of a critical temperature for maximum anaerobic digester biogas production," Multi-Disciplinary Conference, pp. 1-6, 2017.

[43] M. I. Howells, T. Alfstad, D. G. Victor, G. Goldstein, and U. Remme, "A model of household energy services in a lowincome rural African village,” Energy Policy, vol. 33, no. 14, pp. 1833-1851, 2005. 
[44] R. Kalbasi, M. Jahangiri, A. Mosavi et al., "Finding the best station in Belgium to use residential-scale solar heating, one-year dynamic simulation with considering all system losses: economic analysis of using ETSW," Sustainable Energy Technologies and Assessments, vol. 45, p. 101097, 2021.

[45] O. Shela, "Management of shared river basins: the case of the Zambezi river," Water Policy, vol. 2, no. 1-2, pp. 65-81, 2000.

[46] H. H. Savenije and P. Van der Zaag, "Conceptual framework for the management of shared river basins; with special reference to the SADC and EU," Water Policy, vol. 2, no. 1-2, pp. 9-45, 2000.

[47] L. Beck and T. Bernauer, "How will combined changes in water demand and climate affect water availability in the Zambezi river basin?," Global Environmental Change, vol. 21, no. 3, pp. 1061-1072, 2011.

[48] S. Karekezi and J. Kimani, "Status of power sector reform in Africa: impact on the poor," Energy Policy, vol. 30, no. 11-12, pp. 923-945, 2002.

[49] Zambia Development Agency, Zambia Energy Sector Profile, 2014. 